\title{
BUILDING AND CONSTRUCTIVE MATERIALS AS AN URBAN GEOLOGICAL RESOURCE IN TRIKALA PERFECURE
}

\author{
Bathrellos G. D. ${ }^{1}$, Skilodimou H. D. ${ }^{1}$, and Chrysanthaki I. ${ }^{2}$ \\ ${ }^{1}$ National and Kapodistrian University of Athens, Faculty of Geology and Geoenvironment, \\ Department of Geeography - Climatology,gbathrellos@geol.uoa.gr,hskilodimou@euof.uoa.gr \\ ${ }^{2}$ Region of Attica, 56 ${ }^{\text {th }}$ Katechaki Str., 115 25, Athens, ihrisanthaki@attica.gr
}

\begin{abstract}
In this study were investigated the building and constrictive materials in the settlements of Trikala prefecture. These settlements have a long history of housing with buildings constructed by a variety rock types from very different geological settings.

In the modern human and urban constructions are used mainly materials that have been suffered secondary (industrial) elaboration, such as cement, asphalt, glass and building iron. In older constructions (streets, homes, stables, bridges, etc) the man used materials, which the most came from local excavations.

The used domestic natural materials in the human older constructions are attractive, as well as suited with the physical environment. On the contrary, the modern materials are usually strange and unsuitable to natural environment.

The usage of rich and various geological resources in the urban regions present perhaps the best occasion for achieving the connection between the human culture and urban growth with the geology.
\end{abstract}

Key words: excavations, natural materials, urban development.

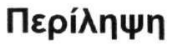

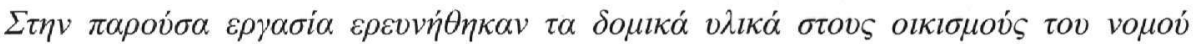

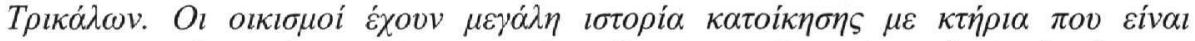

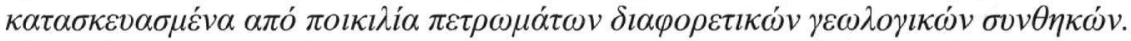

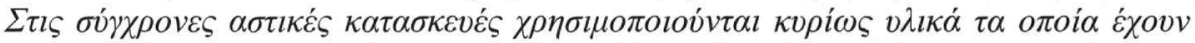

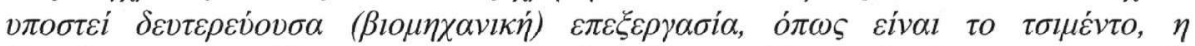

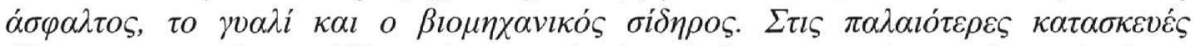

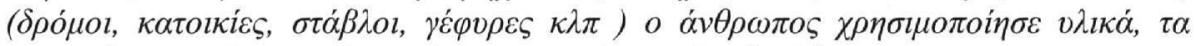

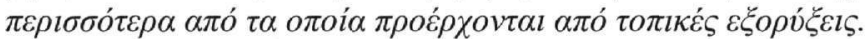

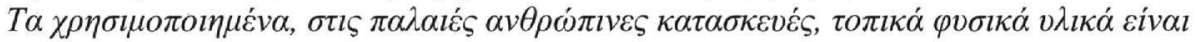

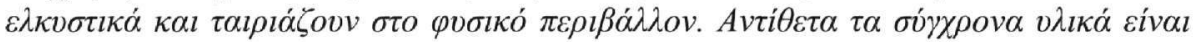

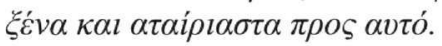

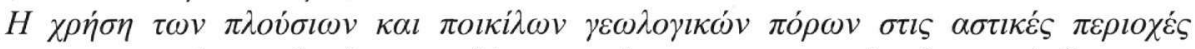

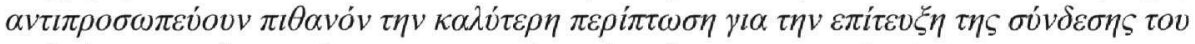

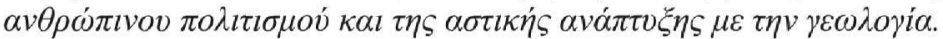

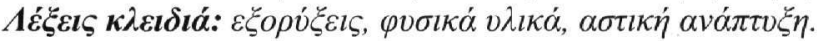




\section{Introduction}

Site conservation is the most important focus for earth heritage conservation within rural areas. Sites-quarries, pits, natural outcrops and landforms are rare in urban environment in contrary the buildings, bridges, stone fences etc are frequently appeared.

Urban geology, especially the origin and quality of building stones has charmed geologists in the Great Britain, since the end of the 19 th century. Charles Kingsley, in 1871, presented a series of lectures to the Chester Natural History Society, dealing with topics such as "the stones in the walls" and "the slate in the roofs", clearly addressing the presence of geology in the growth of towns and cities (Larwood and Prosser 1996). In the early part of 20 th century the Elsden and the Howe (1923) argued the diversity of building stones and materials, which were met in London.

This study demonstrates one of the scopes of urban geological recourse and its role in wider earth heritage conservation. It is examined a subfield of urban geology, which deals with the research and the management of natural resources and materials that are essential and used in the human constructions.

The building and constrictive materials were studied in the settlements of Trikala prefecture. These settlements were chosen because they have a long history of housing with buildings constructed in a variety rock types, and they are located in very different geological settings.

\section{Sources and Methods}

In this study, the data on types of stones used in urban constructions and the location of the visible remains were collected by field observations. In addition the local material excavations were recorded by the field work.

Information on specific buildings, bridges, fountains (Triantafyllou 1979, Katsogiannos 1988, Leak 1996, Kliafa 1997, Leak 2000, Katsogiannos 2001, Gorgogetas 2004) was also consulted. A similar study in Great Britain, written by J. Dove (1996), was taken account. All these references and the collected data were then used to investigate the stone types used in buildings.

\section{Material excavations}

The materials from excavations have been used in the buildings and constructions of towns and settlements of the study area. Because of this it was considered necessary to investigate the material excavations which are used in constructions. It was recorded three types of excavations.

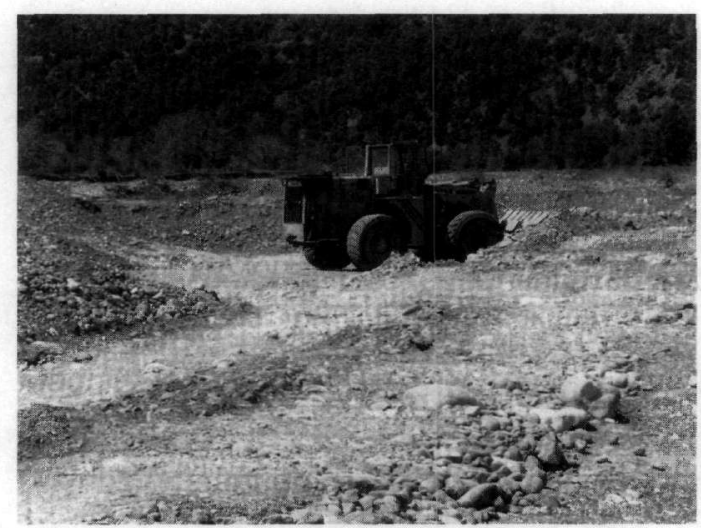

Figure 1 - Sand quarrying in Pineios River

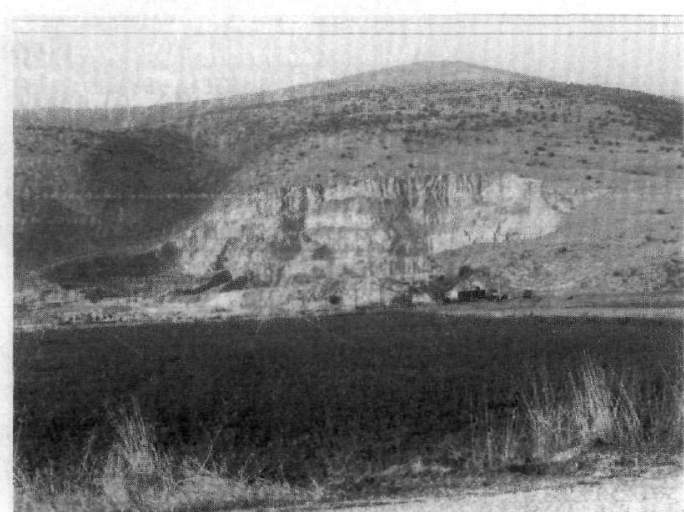

Figure 2 - Quarry of inactive materials in Petroporo village 
The first type is the locations of sand quarrying. These quarrying were recognized mainly in the riverbeds where the slope is gentle (Fig. 1).

In addition in the same area was found quarries excavation of inactive materials and building or decorative stones. In the figure 2 appears a quarry of inactive materials in Petroporo village, in the street from Trikala to Larissa and in figure 3 it appears an old abandoned quarry of marble excavation in the street from Theopetra to Koniskos villages.

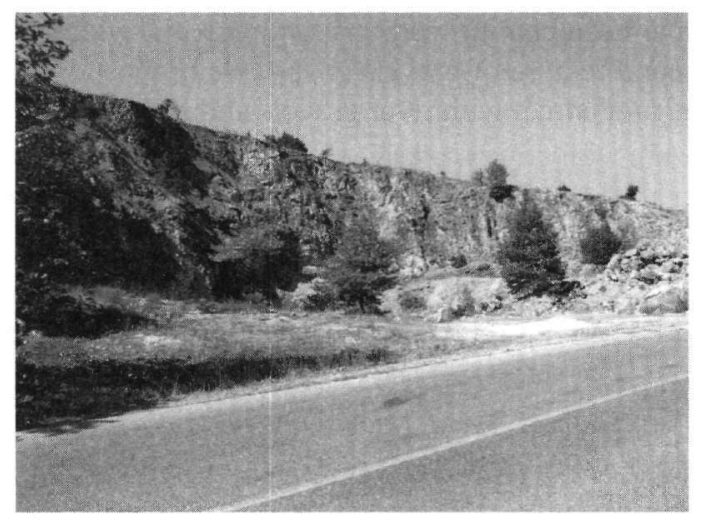

\section{Figure 3-Abandoned quarry of marble excavation}

The third type of materials excavation is the clay minerals which used in the manufacture of bricks and tiles. Potteries is scattered in the prefecture. For the potteries installation and operation was necessary the supplying of suitable clay mineral and water from the adjacent region.

\section{The usage of materials in urban constructions}

In the modern human and urban constructions are used mainly materials that are produced by natural products, but that have been suffered secondary (industrial) elaboration, such as cement, asphalt, glass and building iron.

By observing and recording the materials that were used in older constructions (streets, home, stables, bridges, etc), we conclude that the most of these materials came from local excavations. The huge cost of transporting of heavy materials, such as stones, confined early builders to use local rock types. These are used either in their initial form, or after a primary elaboration such as hewing. During the last decades, these materials have been abandoned, because of the high total elaboration cost. Nowadays, the man uses in constructions mainly manufactured materials (Bathrellos 2005).

The used domestic natural materials in the human older constructions are attractive, as well as suited with the physical environment. On the contrary, the modern materials are usually strange and unsuitable to natural environment. Another advantage in the usage of natural materials has been the support of the local economy. These materials have been produced and disposed in the same region. With the utilisation of modern industrial materials in the constructions are encouraged the material and constructional companies, which usually are established and activated in the urban or suburban areas.

Because of the recent urban provisions and restrictions in some settlements, it is allowed the construction of firm building type. Preservable architecture is utilized in these buildings and used stated materials, which harmonize with the natural or the older built-up environment.

Beyond the provisions and prohibitions, nowadays it is initially recorded a returned tendency in designing and construction of buildings to older architectural types. This tendency is due to the 
recognition of magnificence of old constructions. The cost of these constructions may be higher than the modern ones.

Local stones, of various rock types, from different geological settings were used for older constructions in Trikala prefecture. Such local stones were cherts, limestones, sandstones, conglomerates, as well as pebbles and gravels. These natural materials were used for streets, bridges, churches, temples, houses, storehouses, stone fences, fountains, etc.

Rural streets and roads have been coating with grit and gravels, which come from sand quarrying in adjacent rivers. The mineral texture of gravels is variable proportionately at position. In figure 4 is illustrated the coating of rural street with river gravels and sand at Karavoporos.

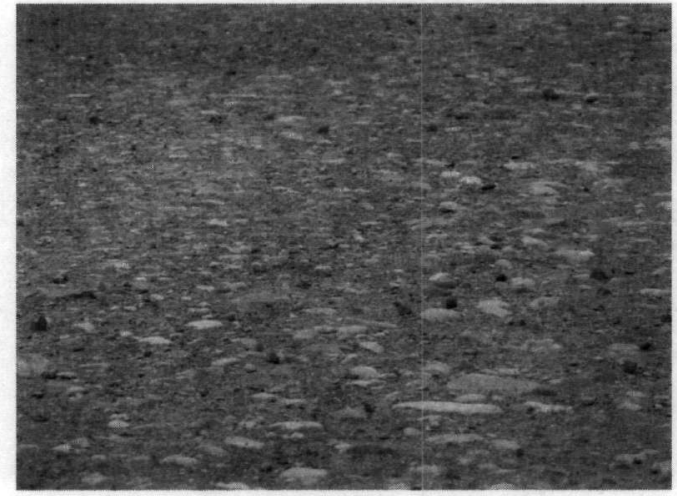

Figure 4-A rural road at Karavoporos

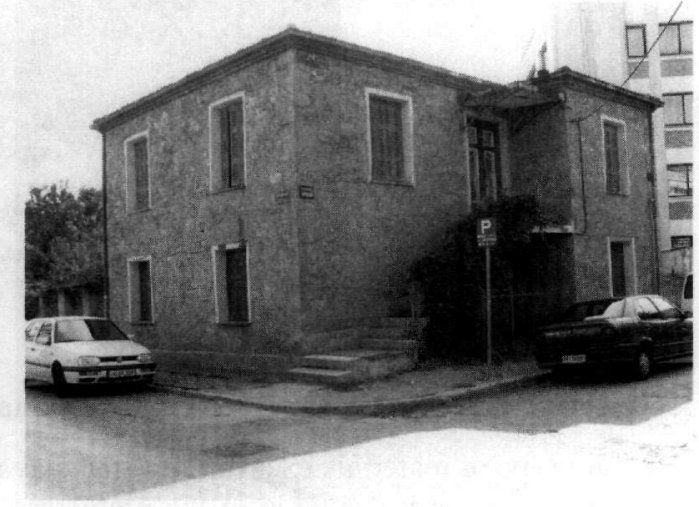

Figure 5 - House made of sandstone in Trikala town

Sandstones were usually used as building stones. These stones come from sandstone horizons of molasses formations which outcrop in the study area. Remarkable is that abandoned sandstone quarries are located northern of Trikala town, in its suburb named Leptokaria. These quarries during the German Occupation, in II World War, were used as execution positions. figures 5 and 6 picture stone built buildings in Trikala town.

In the figures 7 and 8 are appeared buildings in Trikala town that were constructed by using the same materials (sandstones) with alternations of compact ceramic elements. The first one (Fig. 7) is the Koursoum Mosque, which was built from Souleiman Sultan $(1520-1566)$. The second building are Turkish Baths (Fig. 8), which were built, in 1897, during the second Turkish Occupation in Trikala town. At the present time this building operates as a bar.

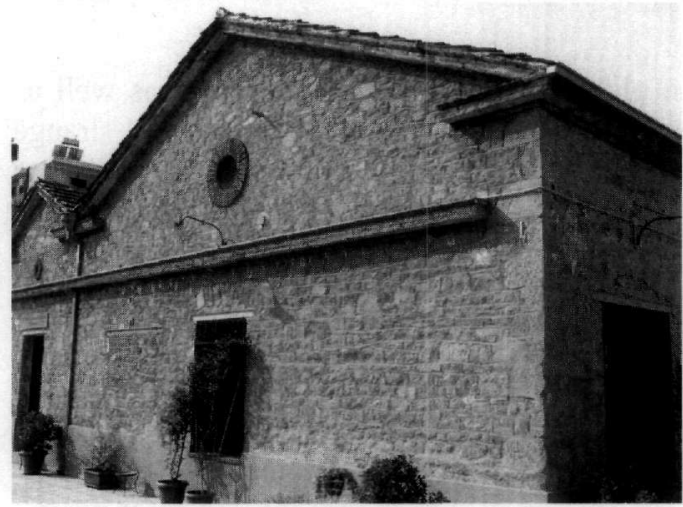

Figure 6 - Old cold store made of sandstone in Trikala town

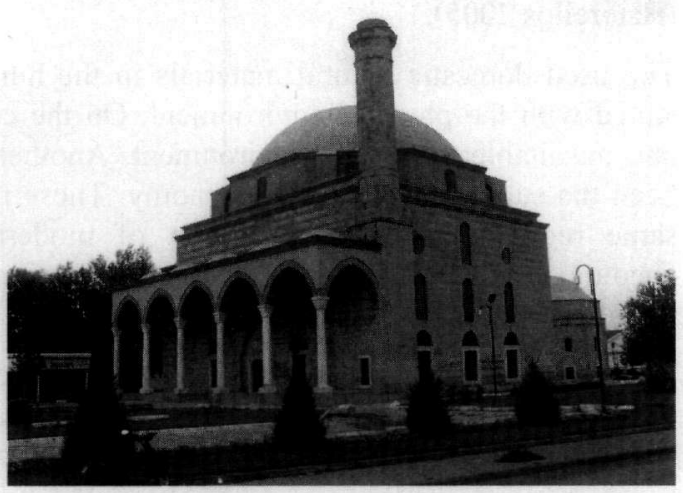

Figure 7 - The Koursoum Mosque made of sandstone and ceramic elements in Trikala town 
Hand-made bricks were more widespread as building material in the nineteenth century in the study area. The bricks were manufactured in many potteries, which are situated around Trikala town (Fig. 9). These potteries were called in the native idiom as "keramaria". At the present time modern potteries are scattered in the flat zone of Trikala prefecture (Fig. 10).

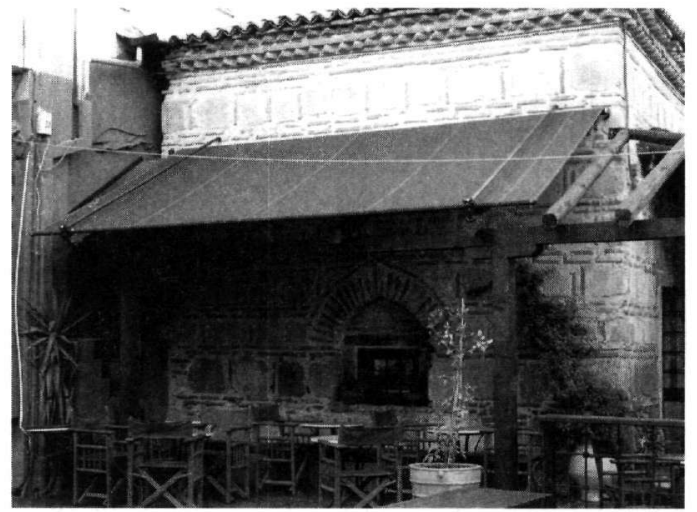

Figure 8 - The Turkish Baths made of sandstone and ceramic elements in Trikala town

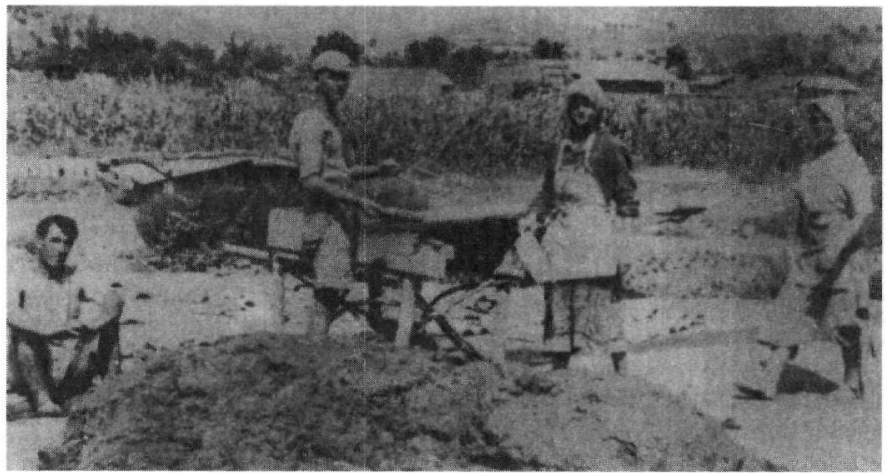

Figure 9 - Old pottery (Katsogiannos 2001)

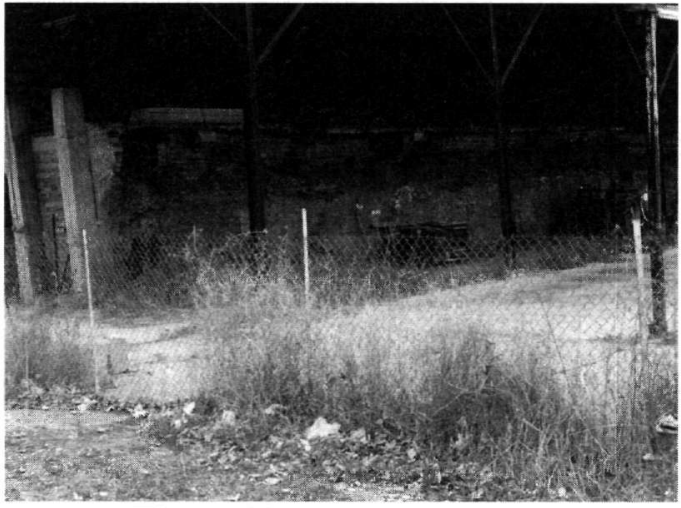

Figure 10 - Modern pottery

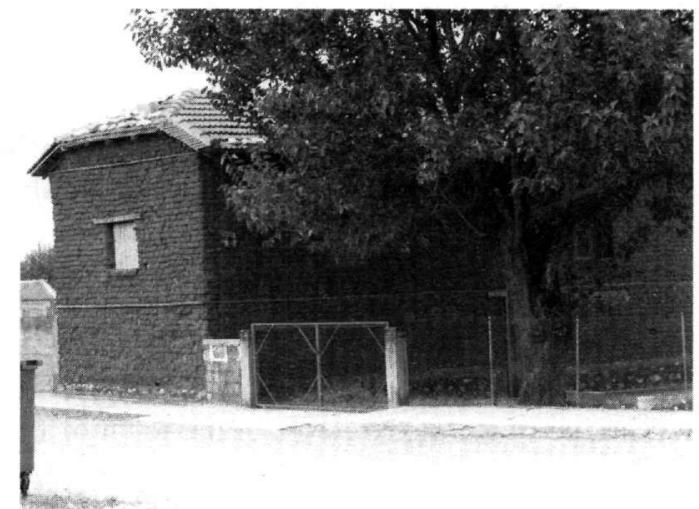

Figure 11 - Stable made of mud-bricks

Another application of clay minerals in the constructions is the mud-bricks. The usage of mudbricks was widespread in the settlements of the flat zone of the study area. In the present time they are used for construction of stables or storehouses (Fig. 11). In the past they were used for housing, but they were abandoned after the extended damages and many loss lives, during the historical flood in 1907 at Trikala town (Fig. 12). 


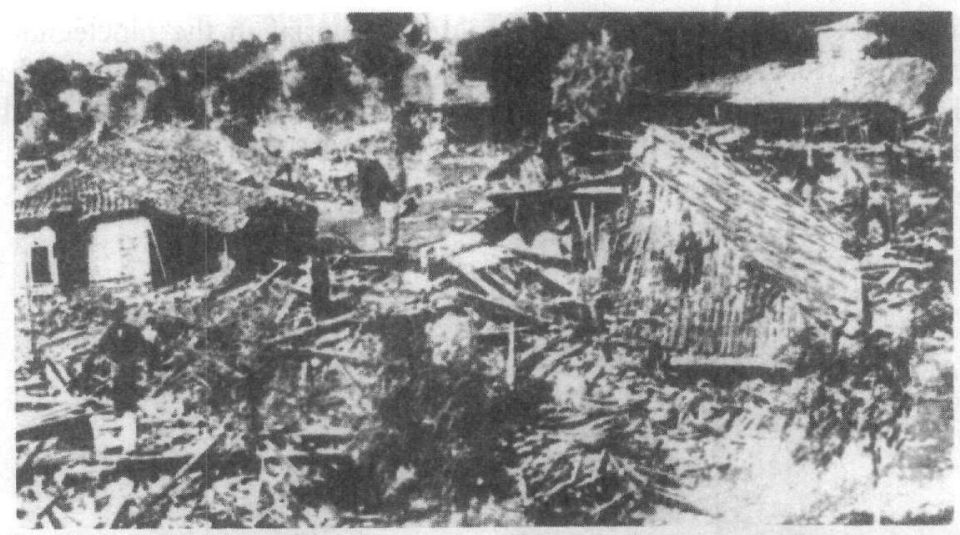

Figure 12 - Extended damages in mud-bricks made houses (Katsogiannos 1988)

In some cases, pebbles, come from the river beds, was used as building stone for walls and fences. figure 13 shows detail of a house wall built with pebbles in Sarakina village. The pebbles derived from the Pineios River bed. In figure 14 appears a stone fence made of pebbles in Palaiomonastiro village. The materials were brought by the Portaikos river bed.

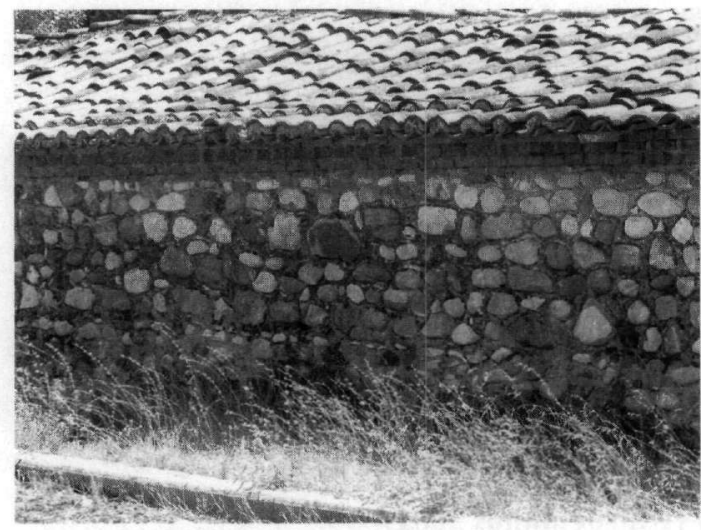

Figure 13 - Detail of pebble made house wall

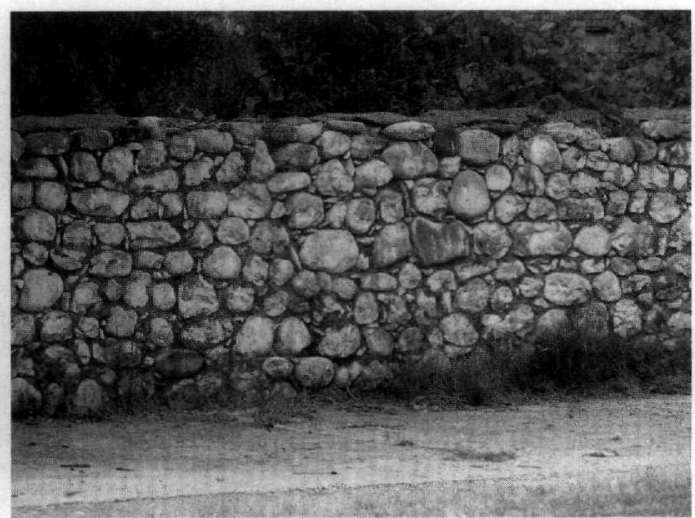

Figure 14 - Stone fence made of pebbles in Palaiomonastiro village

Moreover, freestones brought from proximate regions were used to build the constructions. For example freestones were occasionally used in Xirokampos village in the constructions (Fig. 15). The stones of the wall were getting from talus cones near the village. Talus cones consist of ophiolite and molasse formations materials.

Another example is illustrated in figure 16. The retaining walls in the road in Meteora were constructed by sandstones and conglomerates of molasse formations.

Different freestones were used as building materials in the constructions. Characteristic case is the old bridge of Portaikos River in the town of Pyli. As it is shown in figure 17 limestones, cherts, pebbles etc were used for the building of the bridge.

Besides, varied sedimentary rocks were used in the constructions of the study area. The limestones were often used as a building material in the past and it continues to be used also today. In figure 18 is illustrated limestone, which was used in the construction of the house in the Elati village. 


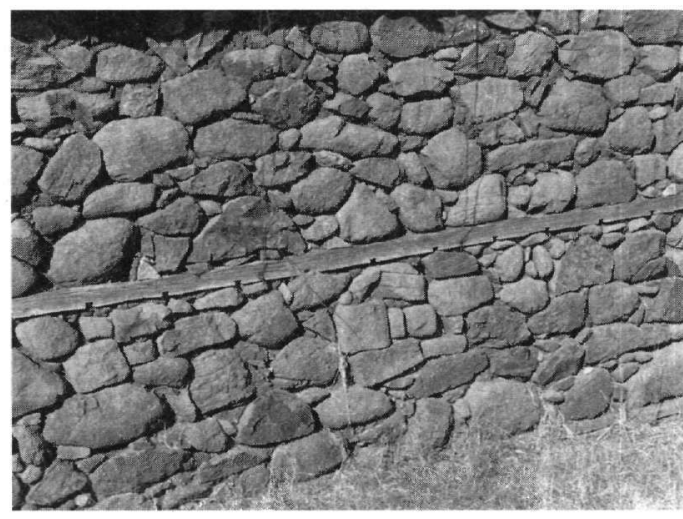

Figure 15 - House wall made of freestone

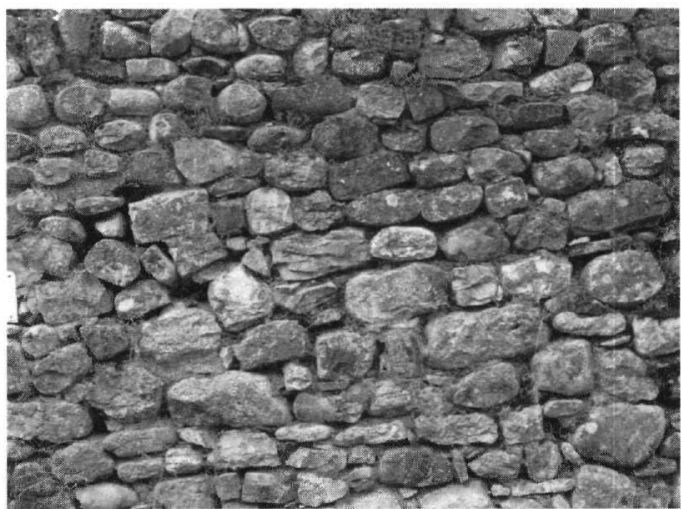

Figure 17 - Detail of the old bridge in Portaikos River

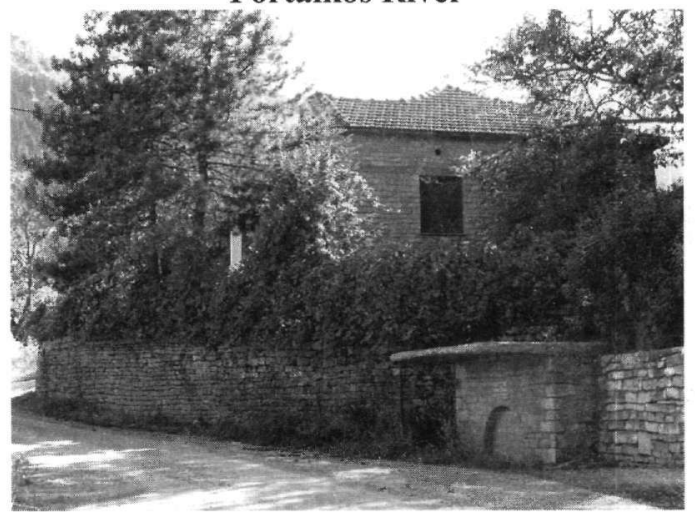

Figure 19 - House, fence and fountain built by cherts in Kleinos village

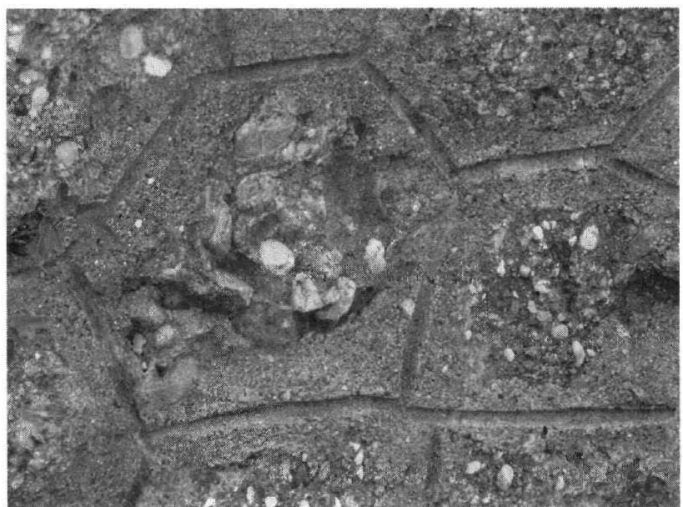

Figure 16 - Part of retaining wall showing conglomerates

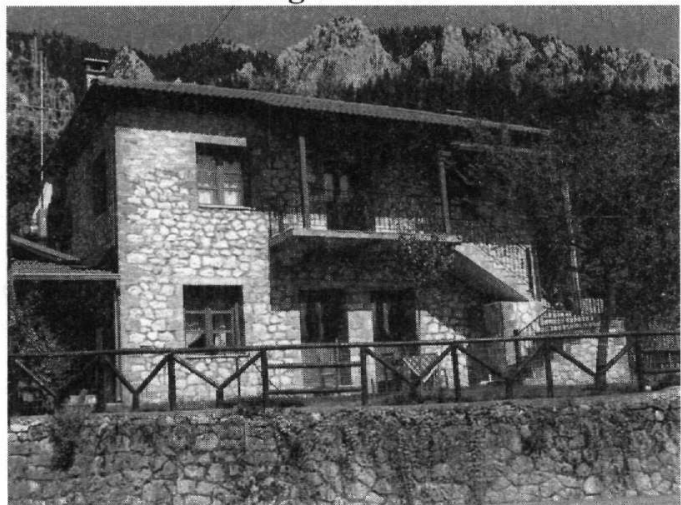

Figure 18 - House built by limestone in Elati village

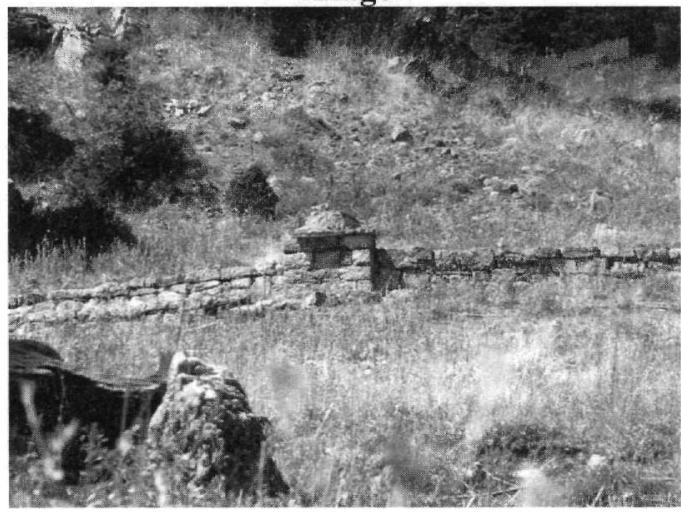

Figure 20 - Fountain constructed by cherts in Gropa

In addition certs abound in the study area. They are used widespread in several constructions mainly in the mountainous part of the Trikala perfecture. Cherts were used for houses, fences and fountains in Kleinos village. The fountain and a part of fence were constructed after the house in different chronic period. In both cases the material were brought by adjacent excavations (Fig. 19).

Another example is shown in figure 20. A fountain was constructed by cherts and it is located in a mountainous area at southwestern part of Trikala prefecture named Gropa.

Finally, in the figure 21 is illustrated a part of house wall in Vrontero village. Materials of adjacent flysch formations were used for the house construction. 


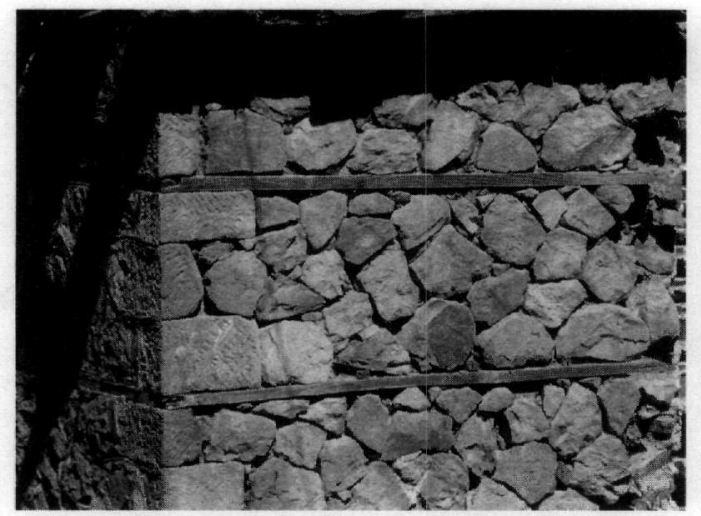

Figure 21 - Detail of house wall in Vrontero village

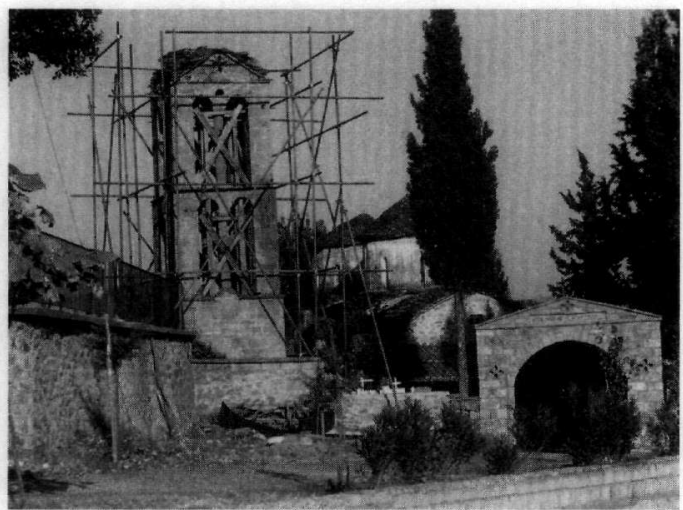

Figure 22 - St. George church in Oxinia village

Local stones were widely used for the bridges and churches in the past centuries in the study area. Today they are used mainly for the erection or reconstructions of those constructions. In figures 22,23 and 24 are pictured a church, bridges, as well as their erections in several locations of the Trikala prefecture.

The use of variety rock types in constructions of settlements which are located in very different geological settings proves that the development of urban areas is straightly related with geology. For this reasons our urban areas provide perhaps the best opportunity to demonstrate the value of geology and in consequence the need of geological conversation in modern society.

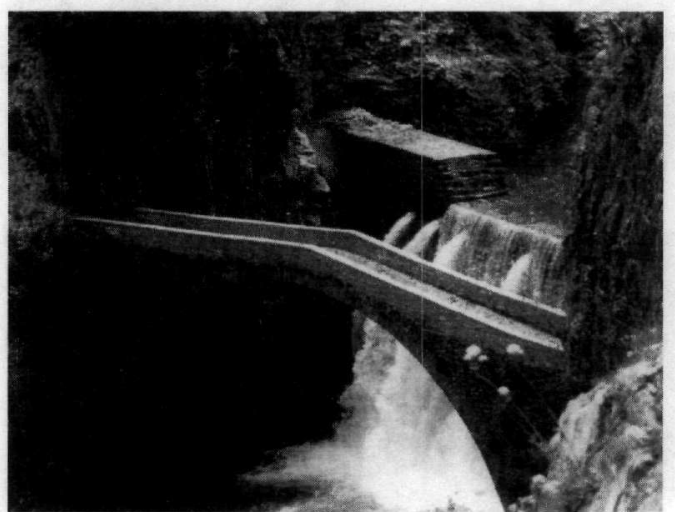

Figure 23 - The reconstructed old bridge at Paleokaria village

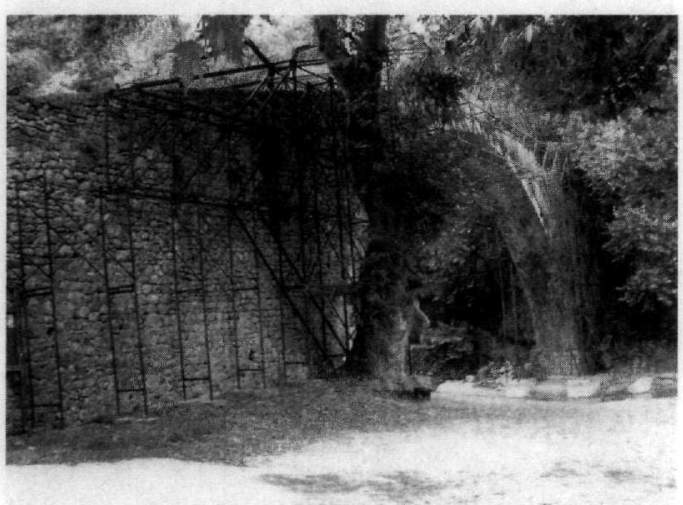

Figure 24 - The old bridge in Portaikos river

\section{Conclusions}

The usage of rich and various geological resources in the urban regions present perhaps the best occasion for achieving the connection between the human culture and urban growth with the geology.

The materials from excavations have been used in the buildings and constructions of the settlements in Trikala prefecture. Because of this it was considered necessary to investigate the material excavations, which are used in constructions. Three types of excavations were recorded, sand quarrying, quarries excavation of inactive materials and building or decorative stones as well as excavation of clay minerals. These materials are used in the coating of rural street and roads and are brought by bordering excavations.

In the past, building and decorative stones were used in many constructions, such as bridges, churches, temples, houses, storehouses, stone fences, fountains, etc. Nowadays these materials are 
usually used for the erection or reconstruction of older constructions. In the present time modern industrial materials are used in the constructions, which are unsuitable the natural environment.

The constructions of settlements are molded by the underlying and surrounding geology. The cost of transporting a heavy material such stones confined the buildings to using local rock types. It is resulted in the mountainous part of the Trikala prefecture, limestones and cherts of Pindos zone are usually used in the constructions. On the contrary in the semi-mountainous and flat zone pebbles, mud-bricks, sandstones of molasses formations are used as building stones. In some cases, different materials are used in the same construction, as we observed in the old bridge in town of Pyli.

\section{References}

Bathrellos, G., 2005. Geological, geomorphological and geographic study of urban areas in Trikala Prefecture - Western Thessaly, PhD Thesis, National and Kapodistrian Univ. Athens, Greece, $567 \mathrm{pp}$.

Bennet, M., Doyle, P., Larwood, J., and Prosser, C., 1996. Geology on your Doorstep, The Geological Society, Publications, 270pp.

Dove, J., 1996. Exeter and Norwich: their urban geology compared during medieval, Victorian and Enduardian periods. In M. Bennet, P. Doyle, J. Larwood and C. Prosser (eds), Geology on your Doorstep. p. 171 - 180, The Geological Society, Publications, 270pp.

Elsden, J.V., and Howe, J.A., 1923. The stones of London, Colliery Guardian Co. London.

Gorgogetas, S.A., 2004. The stone-bridges in Trikala prefecture,.Cult. Org. of Mun. of Aithikon, Publications, $215 \mathrm{pp}$

Katsogiannos, N., 1988. Trikala before and now, Cult. Org. of Mun. of Trikkaion Publications, 224pp.

Katsogiannos, N., 2001. Trikala and its settlements, Cult. Org. of Mun. of Trikkaion Publications, 420pp.

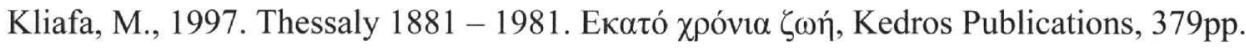

Larwood, J.G., and Prosser, C.D., 1996. The nature of the urban geological resource: an overview. In M. Bennet, P. Doyle, J. Larwood and C. Prosser (eds), Geology on your Doorstep. The Geological Society, p. 19 - 30, The Geological Society, Publications, 270pp.

Leak, W., 1996. Travel in Thessaly of 1809, Translation of Karaiskou G. Thessalian Timetable, $29.33-74$.

Leak, W., 2000. Travel in Thessaly of $1809-1810$, Translation of Argyrouli V. Thessalian Timetable, 38. $144-172$.

Triantafyllou, Th., 1972. Old Trikala - Memories and stories, Typo-Ellinismou Publications $254 \mathrm{pp}$. 